\title{
'Les années de braise' reconsidered: literary representations of Mauritian independence, fifty years on
}

Article

Accepted Version

Waters, J. (2018) 'Les années de braise' reconsidered: literary representations of Mauritian independence, fifty years on.

South Asian Diaspora, 10 (2). pp. 75-90. ISSN 1943-8192 doi: https://doi.org/10.1080/19438192.2018.1460913 Available at https://centaur.reading.ac.uk/76131/

It is advisable to refer to the publisher's version if you intend to cite from the work. See Guidance on citing.

To link to this article DOI: http://dx.doi.org/10.1080/19438192.2018.1460913

Publisher: Taylor and Francis

All outputs in CentAUR are protected by Intellectual Property Rights law, including copyright law. Copyright and IPR is retained by the creators or other copyright holders. Terms and conditions for use of this material are defined in the End User Agreement.

www.reading.ac.uk/centaur 
Central Archive at the University of Reading

Reading's research outputs online 


\title{
'Les années de braise'1 reconsidered: \\ Literary Representations of Mauritian Independence, Fifty Years On
}

\author{
Julia Waters \\ University of Reading, U.K.
}

\begin{abstract}
On 12 March 1968, Mauritius celebrated independence from Great Britain. This article explores how the independence period is represented, fifty years later, in a selection of recent Mauritian novels. Focusing upon long-silenced inter-ethnic tensions, inequalities and exclusions, these twenty-first-century fictional works deconstruct dominant celebratory narratives of Mauritius's multicultural 'rainbow nation.' By retrospectively revealing cracks in the nation's harmonious façade, the article argues, the novels' counter-discursive narratives of the nation's foundation play an important part in an ongoing, forward-looking project of nation-building that envisages more inclusive, non-ethnic forms of 'unity in diversity.'
\end{abstract}

Keywords: Mauritian literature; independence; inter-ethnic violence; nation-building

Fifty years on from the official handover of power from Great Britain, on 12 March 1968, Mauritian independence has emerged as the subject of a number of recent Mauritian novels. These often highly critical fictional representations of the birth of the new, post-colonial nation are strikingly different in content and tone from the positive, self-congratulatory images officially promoted by politicians, keen to celebrate the young nation's many successes. Given the dire predictions of Mauritius's prospects at the time of independence (Allen 1966; Naipaul 1972), ${ }^{2}$ successive post-colonial governments certainly have much to be proud of: defying expectations, Mauritius has, over the past fifty years, gone on to be heralded as an 'African success story' (Frankel 2010), 'an economic miracle' (Minogue 1992; Subramanian and Roy 2003) and a 'model postcolonial state' (Lionnet 1993, p. 106), widely praised for the peaceful accommodation of its multi-ethnic population. ${ }^{3}$

Yet, the independence period was for many a profoundly traumatic time, marked by violent inter-ethnic unrest - between Hindus and Creoles (Afro-Mauritians), but also between Muslims and Creoles - and by the emigration of large numbers of Franco-Mauritians and 
middle-class Creoles. ${ }^{4}$ Ironically, so intense was the violence during the months leading up to independence, that British troops had to be deployed in order to restore an uneasy peace. Such was the fear of inter-ethnic violence that the independence ceremony itself, boycotted by large sections of the population, was held at midday, rather than at the usual, more symbolic time of midnight. This article aims to analyse how the independence period is represented in the following twenty-first-century Mauritian novels: Shenaz Patel's Le Silence des Chagos (The Silence of the Chagos) (2005); Ananda Devi's Le Sari vert (The Green Sari) (2009); Amal Sewtohul's Made in Mauritius (2012); and Alain Gordon-Gentil's J'attendrai la fin du monde (I'll Wait for the End of the World) (2016), all of which focus, in different ways, upon tensions, inequalities and exclusions that have until recently largely remained taboo. I shall also consider how the purportedly historic, foundational moment of the handover ceremony itself is depicted, fifty years on. By analysing differences and convergences between the novels' retrospective representations of Mauritian independence, I shall examine what kind of picture is collectively painted of the nation's foundation, and what this might suggest about the perceived state of race relations in Mauritius's multi-ethnic, post-colonial nation today.

What is often overlooked in the official rhetoric celebrating Mauritius's post-colonial half-century is that nearly half of the population at the time vehemently opposed independence. Hindu-Mauritians (comprising nearly 50\% of the population at the time) were predominantly in favour of independence, seeing it as an opportunity to secure for themselves greater political, economic and social influence. The vast majority of other ethnic groups, however, opposed independence, fearing that it would lead to the 'Indianisation' of the island and their own marginalisation. This ethnically-delineated division of opinion was presciently highlighted by Philip Allen when he identified three competing ethnic 'worlds' within Mauritian society: 
Mauritius is indeed 'multiracial' but it has never [...] developed a strong national sense that cuts across communal lines. Ill feeling between the communities has in fact intensified with the approach of national independence. The world of the Hindu canefield proletariat stands in opposition not only to the occidental world of the Franco-Mauritian and Creole, but also to the 'third world' of discrete oriental minorities - the Moslems, Chinese, and Tamils. Like the occidentals, most members of this third world view the coming of independence with some apprehension, for to them it means a withdrawal of British protection and an endorsement of Hindu sovereignty. $(1966,18)$

This ill feeling between competing ethnic worlds ${ }^{5}$ continues to lurk below the surface of the nation's proclaimed multicultural unity even today and hence to colour the ways in which independence is remembered or, indeed, forgotten.

The turbulent circumstances of Mauritius's transition to independence have ever since been largely glossed over, avoided or silenced by politicians and commentators. As the writer and activist Lindsey Collen (2009) notes, with regard to the many crimes committed in the lead-up to independence, 'there were no trials afterwards. The deaths, maimings and rapes lie buried in shallow memories, as if any attempt by the State to bring anyone to trial might put a spark to the inflammable materials that are us'. ${ }^{6}$ Until recently, the trauma and divisions of the independence period have therefore been largely occluded, in a concerted effort to portray a positive image of Mauritius's rainbow nation, both internally and to the outside world. Successive (mainly Hindu-led) governments, anxious to avoid a recurrence of the inter-ethnic violence of the pre-independence period, have adopted a pragmatic multicultural model, which seeks to represent the interests of all sections of the island's diverse population under the purportedly inclusive national banner of 'unity in diversity'. ${ }^{7}$ Despite constitutional minority safeguards established to give substance to such inclusive political rhetoric, ${ }^{8}$ the Hindu majority's demographic dominance has in fact ensured its own hegemonic dominance in most areas of Mauritian life, so fuelling a growing sense of disaffection and malaise amongst other ethnic groups, especially impoverished Creoles (Boswell 2006). In this context, it is striking - and, with hindsight, ironic - to note how many commentators have 
based their enthusiastic praise for Mauritius's post-colonial, multicultural model on the lack of a recurrence of the inter-ethnic violence that so marred the transition to independence, rather than on evidence of more positive forms of contemporary social cohesion. ${ }^{9}$

\section{Recent literary representations of Mauritian independence}

In 1999, violent, inter-ethnic unrest broke out across the country, following the suspicious death in police custody of the popular Creole singer, Kaya. The 'Kaya riots' revealed deep economic inequalities and long-simmering ethnic divisions behind the post-independence façade of inter-cultural harmony. Destabilising complacent assumptions of the success of Mauritius's multicultural model, the riots reawakened painful memories of the social unrest of the pre-independence period. In the wake of the 1999 unrest, recent Mauritian fiction has begun to revisit the circumstances of the nation's foundation with a more critical, even iconoclastic eye, and to shine a light on dark, long-suppressed aspects of this muchcelebrated historical moment. ${ }^{10}$ Given the veil of silence that has long shrouded the internecine unrest of the late 1960s, I aim to explore in this article how the independence period is retrospectively represented in novels written after the Kaya riots, in the aftermath of which inter-ethnic relations and social inequality in Mauritius were again forced onto political and cultural agendas.

Shenaz Patel's Le Silence des Chagos recounts the fictionalised testimonies of reallife Chagossian refugees - the long-unacknowledged victims of secretive British, American and Mauritian Cold War machinations - who were forcibly displaced from their islands in the late 1960s and early 1970s as a pre-condition of Mauritian independence, in order to make way for a US military base. In Ananda Devi’s Le Sari vert, the dying Hindu-Mauritian narrator and purported 'héros de l'indépendance (hero of independence)' (95) retrospectively 
tells the story of his early life with his wife, in which his own racism, misogyny and murderous violence are set against the turbulent backdrop of the independence years. Amal Sewtohul's Made in Mauritius is dedicated 'à tous les Mauriciens de la génération de l'Indépendance (to all Mauritians of the Independence generation)' and tells the fictional lifestory of the second-generation Sino-Mauritian, Laval, intertwined with that of Mauritius's accession to independence. Finally, Alain Gordon-Gentil's J'attendrai la fin du monde recounts the inter-ethnic tensions and socio-political upheavals of the late 1960s, as narrated retrospectively by the mixed-race journalist, Horace Baudelaire who, ${ }^{11}$ though privately in favour of independence, publicly spent the pre-independence period writing antiindependence propaganda which was 'à rebours de ses convictions profondes (against his own deeply-held convictions)' (back-cover blurb). As I shall explore, the novels collectively paint a highly critical picture of the island's turbulent and contested transition to independence, so questioning dominant, celebratory images of Mauritius as a harmonious, multi-cultural 'rainbow nation'. Nonetheless, I shall consider in conclusion how these seemingly negative, iconoclastic representations of Mauritius's foundation might be seen to contribute, more constructively, to alternative, more inclusive conceptions of Mauritian nationhood, fifty years on.

The transition to independence in Mauritius 'was not', as Houbert remarks, 'the outcome of a national liberation struggle' $(1981,104)$. This perhaps surprising lack of anticolonial sentiment has its roots in the particular circumstances of Mauritius's history of dual colonisation. Although Mauritius was a British colony (from 1810 to 1968) for longer than it had been a French one (1715-1810), the British never attempted to settle the island or to impose British culture on its inhabitants. Administering the colony's commercial and political interests as a strategic trading post, the British allowed the pre-existing Franco-Mauritian (and Creole) society to maintain its own religious, linguistic and cultural traditions, as well as 
to retain ownership of most of the land and businesses. As a result, when independence was mooted, it was seen by Franco-Mauritians and by better-off, French-speaking, Catholic Creoles, as a threat to their own (real or aspirational) links with France, rather than with Britain itself. This paradoxical situation is explored in J'attendrai la fin du monde via the central, fictional relationship between the mixed-race (Creole and French) protagonist, Horace Baudelaire, and Aansa, the Anglo-Indian daughter of the British governor, John Fitzgibbon. ${ }^{12}$ The violence of the pre-independence period is shown to be targeted not at the departing colonial authorities but, rather, at fellow Mauritians from different ethnic groups. Indeed, 'pendant les émeutes raciales, le père d'Aansa a su garder un sang-froid remarquable et surtout être perçu par les deux camps comme un homme sans parti pris et totalement indépendant (During the race riots, Aansa's father managed to keep a remarkably cool head and especially to be seen by both sides as a man who was without bias and totally independent)' (129). The irony of such a linguistically ambivalent 'independent' stance is further emphasised in the following, more categorical observation: 'Dans ce pays qui avait voté pour l'indépendance et qui allait la célébrer dans quelques mois, il fallait des soldats anglais pour rétablir le sentiment de sécurité (In this country, which had voted for independence and was going to celebrate it in a few months, English soldiers were needed to re-establish law and order)' (77). Although the British colonisation of Mauritius is today still widely viewed as an occupation by the pre-established society of Franco-Mauritians and Creoles, it had nonetheless, as Gordon-Gentil's novel repeatedly underlines, ensured 'deux siècles de culture européenne (two centuries of European culture)' (64) - a culture which, with independence, was now seen as under threat from other, non-European cultures.

Opposition to independence by Franco-Mauritians, Creoles and Muslims was also motivated, as Gordon-Gentil underlines, by their fear of the 'indianisation radicale (radical Indianisation)' (65) of the island by the Hindu demographic majority. In the view of non- 
Hindu Mauritians, 'l'indépendance, c'était le rattachement de Maurice à l'Inde.

(Independence signified the attachment of Mauritius to India)' (Gordon-Gentil 2016, 66). The racial and racist basis of their opposition to independence is most stridently reflected in the anti-Indian views of Raoul Laurent, Chief Editor at Le Vigilant: 'A l'entendre', the narrator remarks, 'il avait voté plus contre les Indiens que contre l'indépendance. Ce qui était sans doute vrai (Listening to him, he had voted more against the Indians than against independence. Which was doubtless true)' (49). Similarly, when large numbers of FrancoMauritians and 'gens de couleur (people of colour)' decide to emigrate rather than see power pass to "ces descendants de coolies qui [...] "pensaient pouvoir diriger un pays" (these descendants of coolies who "thought they could lead a country")' (50), Horace underlines the racism behind their decision when he caustically observes that: 'parmi ceux qui partaient il y en avait qui n'arrivaient pas à prononcer les deux mots [Océan Indien] l'un après l'autre. Tellement le deuxième leur paraissait immonde' (amongst those who were leaving there were some who couldn't bring themselves to pronounce the two words [Indian Ocean] one after the other. So vile did the second seem to them)' (97). 'S'ils voulaient tous partir pour l'Australie,' he concludes,' c'est qu'ils étaient racistes (If they all wanted to leave for Australia, it's because they were racist) ${ }^{\prime 13}$ (95) - a particularly ironic judgement from someone who had earned a comfortable living and considerable renown from stoking precisely such anti-Hindu, anti-independence sentiments.

Ananda Devi takes a rather different approach to the widespread fear of the postindependence 'Indianisation' of Mauritius in her novel, Le Sari vert. The main focus of the novel is on the dying Hindu narrator's gradual revelation of his sadistic, misogynist abuse of his wife and daughter. Yet, the context within which this family saga unfolds - the strikes and inter-ethnic unrest of the pre-independence period - is also revealing for its implicit critique of the communalist self-interest of Hindu proponents of independence. In a key scene 
recounted early in the novel, the newly-married couple are at a reception attended by the nascent Hindu-Mauritian bourgeoisie, when the narrator becomes increasingly angry at what he sees as his wife's socially inappropriate exuberance. Rebuffing her overt show of affection toward him, he recalls:

Je lui ai tourné le dos. J'ai continué à discuter politique avec les hommes qui m'entouraient. Notre anglais était artificiel et pompeux, maladroit et zozotant, mais nous nous sentions différents des autres. [...] Nous construisions l'avenir d'un pays pas encore indépendant. Nous chasserions les Anglais de notre petite île, nous serions les pionniers, nous marcherions sur les traces de Nehru et de Gandhi, nous aurions notre route du sucre pour faire écho à leur route du sel. (I turned my back on her. I continued to talk politics with the men around me. Our English was fake and pompous, clumsy and lisping, but we felt different from the others. We were building the future of a country that wasn't yet independent. We would throw out the English from our little island, we would be pioneers, we would walk in the steps of Nehru and Gandhi, we would have our own Sugar March to mirror their Salt March.) (Devi 2009, 26)

Devi's narrative reveals how Mauritian anti-colonial politics was influenced by the politics of Indian independence: in terms both of the political figures emulated but also, as we shall explore, of the transposed, violent competition between Hindus and Muslims that, in India, had precipitated the partition of the sub-continent. ${ }^{14}$ The grandiloquent plans of the emergent Hindu elite, keen to mimic in microcosm the recent achievements of their Indian role models, are undercut in the above extract both by the narrator's mockery of his peers' pretentious affectations and, more ominously, by his comparison of the island's internecine power struggles with his own domestic disagreements with his wife.

As the novel evolves, the parallel between the narrator's increasingly abusive domination of his wife, on the one hand, and the violent unrest between different ethnic factions during the pre-independence period, on the other, becomes even more mutually revealing, as the narrator seeks to justify his own behaviour by comparing 'la hargne déferlée des deux côtés (the spite unleashed on both sides)' and 'la brûlure du fanatisme [...] sur tous 
ces visages déformés (the intense heat of fanaticism on all of these deformed faces)' with 'mes petites colères quotidiennes, somme toute bien banales et anodines (my ultimately quite banal and inoffensive, daily little angry outbursts)' (Devi 2009, 130). Given the novel's gradual revelation of the physical and psychological abuse to which he subjects his wife, the narrator's assertion that 'j'étais bien meilleur que la plupart des hommes de mon époque (I was much better than most of the men of my era)' (94) is doubly ironic: not only does it emphasise his own sadistic and delusional character but, implicitly, it also serves to bring into question dominant, hagiographical depictions of other 'héros de l'indépendance (heroes of independence)'.

Such debunking of self-aggrandising, celebratory narratives of Mauritian independence is evident in a later episode in Devi's novel, during which the doctor-narrator, on a night visit during pre-independence riots, is stopped at a road-block by Hindu vigilantes and asked to prove his religion (that is, by proving that he is not a circumcised Muslim). Realising, to his embarrassment, that he is wearing tatty underpants, he refuses to drop his trousers, proclaiming that 'tous les hommes sont égaux et ont droit au respect (all men are equal and deserve respect)' (129) - a seemingly defiant act which earns him the adulation of Muslims and Creoles alike. As the narrator reflects:

Des années plus tard, on s'est souvenu de cet incident et je suis devenu l'exemple du vrai Mauricien au moment où l'on en avait le plus besoin. Mon geste a condensé l'espoir d'une jeune nation. Mon nom a été brandi comme le symbole d'une naissance. (Years later, people remembered this incident and I became the example of the true Mauritian at the moment when we needed it most. My act embodied the hopes of a young nation. My name was brandished as the symbol of a new birth.) (31)

In striking contrast to the 'model Mauritian citizen' promoted in earlier, twentieth-century nationalist narratives (Ravi 2010), Devi’s choice of a vain, wife-beating misogynist and racist snob with tatty underpants as 'l'exemple du vrai Mauricien (the example of the true Mauritian)' and 'le symbole d'une naissance (the symbol of a new birth )' speaks volumes for 
her iconoclastic riposte to would-be celebratory grand narratives of Mauritian independence promoted, most stridently, by the dominant Hindu majority. The literary genius of Devi's novel lies in its ability to convey such a counter-discursive stance through the fictional narrative mouthpiece of a (self-)proclaimed national independence 'hero'.

As the novels analysed reflect, opposition to Mauritian independence was motivated, at least in part, by anti-Hindu sentiment and the fear of 'Indianisation'. While GordonGentil's novel is explicitly critical of the racist, anti-Indian motivations behind Creoles' and Franco-Mauritians' anti-independence vote, Devi's choice of a deeply flawed, Hindu narrator more implicitly critiques the ethnically-divisive 'Indianisation' of Mauritian politics at the time, which, in particular, pitted Hindus against Muslims. Focusing on different ethnic and religious groups, Gordon-Gentil's J'attendrai la fin du monde and Amal Sewtohul's Made in Mauritius also explore the more unexpected but sustained violence that erupted between Muslims and Creoles in the months leading up to independence - violence which raised fears of civil war and even threatened to put the transition to independence in jeopardy. ${ }^{15} \mathrm{In}$ contrast to the earlier waves of inter-ethnic violence that Devi's novel depicts, 'what was strange about the violence of 1968', Jean Houbert remarks, 'was that it was between creoles and Muslims, the two ethnic groups which had opposed independence, that it remained localised in a suburb of the capital, and that it occurred after the elections but before independence' $(1981,87)$. As we shall now explore, both Sewtohul's and Gordon-Gentil's novels depict this seemingly inexplicable and long-occluded outbreak of violence, and in so doing, retrospectively imagine fictional answers to the questions that Houbert poses.

Gordon-Gentil and Sewtohul take contrasting approaches to their fictional engagements with the Muslim-Creole violence of the pre-independence period, reflecting their narrators' respective positions: as well-connected insider (Horace) or naïve young bystander (Laval). Although J'attendrai la fin du monde follows the central protagonist's 
globe-trotting travels over more than half a century, its geographic and thematic centre, to which both novel and protagonist repeatedly return, remains Horace's home neighbourhood of Saint François - a suburb of Port Louis that, as the novel emphasises, was radically and irreversibly changed by inter-ethnic violence in the months leading up to independence. ${ }^{16}$ Prior to the immediate pre-independence period, Saint François had been a multi-cultural district, in which Muslims and Creoles had co-existed harmoniously for generations. The effects, nature and possible causes of the profound transformation that the violence wrought on the narrator's physical and sentimental environment are replayed obsessively throughout the novel, as the narrative is punctuated by Horace's repeated, retrospective reflections. Early in the novel, for instance, Horace observes that: 'Depuis les émeutes raciales entre créoles et musulmans au moment de l'indépendance, le quartier s'est vidé de toutes les autres communautés pour devenir un quartier quasi exclusivement musulman (Since the race riots between Creoles and Muslims at the moment of independence, the district has been emptied of all other communities and has become an exclusively Muslim district)' (19). Echoing the observations of Houbert and of real-life eye witnesses, Gordon-Gentil's fictional representation of the violence between former friends, neighbours and political allies repeatedly emphasises the dominant feelings of incomprehension and shock that characterise responses to this dark and suppressed episode of recent Mauritian history:

Depuis quelques semaines, tout avait changé si vite. Avec une telle brutalité. On avait du mal à croire que musulmans et catholiques, à peine quelques mois plus tôt, s'étaient unis pour combattre l'indépendance. (In a few weeks, everything had changed so quickly. With such brutality. It was hard to believe that barely a few months earlier, Muslims and Catholics had fought together against independence.) (Gordon-Gentil 2016, 64)

In both reality and fiction, the social and psychological consequences of the violence between Muslims and Creoles are manifested in spatial form, as Lindsey Collen (2009) poignantly 
underlines: 'The scar between two suburbs of the capital, Plaine Verte and Roche Bois, is still visible: pylons in a wasteland where a no-go area had appeared after the communities separated out'. ${ }^{17}$

Sewtohul's Made in Mauritius takes a very different, light-hearted approach to the depiction of pre-independence violence between Creoles and Muslims in Port Louis. Throughout the novel, the intertwined stories of Laval's life and of the birth of the Mauritian nation are symbolically associated with the multi-faceted trope of a shipping container, in which Laval was born and raised. The container is then present at and - in Laval's superstitious, childhood imagination - instrumental in, key episodes in Mauritius's historical transition to independence. When Laval's father transports the container to the Champ-deMars, where independence is due shortly to be declared, the container's very presence there is seen, in interrelated, realist and fantastic ways, as responsible for sparking a deadly outbreak of inter-ethnic violence. First, the container is used for a shady, match-fixing scam between rival Creole and Muslim gangs. When the scam goes wrong, a gun fight ensues and a gangster is killed, triggering a tit-for-tat escalation of inter-communal violence. Secondly, a politically-motivated cause of the violence, unsuspected at the time by his childhood self, is retrospectively suggested by the adult Laval, when he reflects that:

Lorsqu'un pays se met à s'entre-tuer, ce sont les gens du petit peuple qui se tourmentent et battent leur coulpe, alors que les vrais criminels, les gangsters [...] tout comme les politiciens qui en ce temps-là ameutaient les gens, eux ont la conscience claire. (When a country starts to tear itself apart, it's the little people who are tormented and blame themselves, whereas the real criminals, the gangsters, like the politicians who during that time were stirring people up, they have a clean conscience.) (Sewtohul 2012, 118-119)

Fantastically, thirdly, the young Laval sees the very displacement of the container, by disturbing the status quo, as having precipitated the outbreak of violence. According to such magical-realist narrative logic, the country's fate was decided from the moment Laval's 
father chose to move the container from its usual place in the backyard of the family's shop in Chinatown that morning: 'on était là dans une de ces journées où la vie de tous les jours est perturbée (it was one of those days when everyday life is thrown into confusion)' (110). Both fantastic and realist triggers for the outbreak of otherwise incomprehensible inter-ethnic violence - the displacement of the container, rivalry between criminal gangs, or political manoeuvring - humorously and irreconcilably co-exist in Sewtohul's idiosyncratic engagement with this foundational event in Mauritian history.

In J'attendrai la fin du monde, different causes for the inter-ethnic violence between Creoles and Muslims are also proposed, although, as in Sewtohul's narrative, none is given more credence than the other. According to the vehemently anti-independence and antiIndian character Laurent, the violence was incited by the Hindu-Mauritian majority, who stood to gain from dividing their previously united opponents:

Qui a intérêt à ce que les musulmans et les créoles se bagarrent? Les deux communautés ont voté massivement contre l'indépendance. Les Indiens ont tout à gagner en divisant ceux qui ont voté contre eux! (Who stands to benefit if Muslims and Creoles fight each other? Both communities voted massively against independence. The Indians have everything to gain from dividing those who voted against them!) (Gordon-Gentil 2016, 48-49)

Alternatively, Horace's own bad faith, in writing 'avec conviction, tous les jours, le contraire de ce que l'on pense (with conviction, every day, the opposite of what one believes)' (51), is also implicitly blamed for stoking ethnic divisions that then escalated into sustained violence. For instance, the publication of his sensationalist and exaggerated account of a relatively minor, localised incident of inter-ethnic tension - in which Creoles left a pig carcass outside a mosque in Port Louis - is portrayed as stoking an atmosphere of mutual fear, suspicion and retaliatory violence which, in turn, precipitates the emigration of some of Horace's own friends and colleagues. In contrast to the inflammatory rhetoric of his own journalism, however, Horace hypocritically reflects, 'Nous n'étions pas passés loin, mais mis à part des 
règlements de comptes violents, on ne pouvait pas parler de massacres (We had come close, but apart from some violent settling of scores, one couldn't talk of massacres)' (55).

Both J'attendrai la fin du monde and Made in Mauritius focus on the irreversible upheaval caused by the seemingly incomprehensible pre-independence violence between Muslims and Creoles. Gordon-Gentil portrays this unrest as leading to the enduring ethnic segregation of previously mixed communities. In humorous contrast, however, Sewtohul depicts the upheaval of the period - as Laval, his father and friends flee riot-stricken Port Louis - as the means by which they move beyond the limited boundaries of their own ethnic communities and discover other parts of Mauritius and other Mauritians for the first time. Reflecting a child's insouciant disconnect between personal and official histories, Laval humorously notes that, 'la ville était à feu et à sang, et Feisal, Ayesha et moi nous nous sommes bien amusés (the town was being torn apart, and Feisal, Ayesha and I had a whale of a time)' (Sewtohul 2012, 118). Passing through the districts of Plaine Verte and Tranquebar, beset by inter-ethnic violence, Laval even comments that for him, these were 'les soirées les plus heureuses de ma vie (the happiest evenings of my life)' (122).

My analysis of fictional representations of Mauritian independence, fifty years on, has so far focused on the long-repressed inter-ethnic tensions that marked the pre-independence period. In the next section of this article, I shall explore the ways in which the independence ceremony itself, held on 12 March 1968, is depicted in J'attendrai la fin du monde, Made in Mauritius and Le Silence des Chagos, and examine how the three authors, in different ways and to different ends, debunk official, celebratory narratives of the nation's birth. Both Gordon-Gentil and Sewtohul undermine the historical significance of the independence ceremony by means of the illicit, incongruous presence of the narrator at the scene: GordonGentil, by Horace's attempted suicide at the foot of the official flagpole; and Sewtohul, by Laval's presence, inside the container-cum-podium, on which the handover ceremony takes 
place. Whatever the motives for Horace's bungled suicide attempt - variously interpreted, by different characters, as a sign of mental anguish at his daily hypocrisy; of despair at the imminent departure of the British governor and his daughter; or of protest against independence - his actions have the effect of upstaging the official actors and so spoiling the new nation's auspicious day. Dismissing Horace's selfish gesture, Fitzgibbon comments: 'Vouloir mourir à l'endroit même, le jour même où j'allais descendre l'Union Jack a gâché ce moment historique pour moi mais aussi pour votre pays (Wanting to die at the very spot, on the very day that I was due to lower the Union Jack, spoilt this historic moment for me but also for your country)' (Gordon-Gentil 2016, 130).

In Made in Mauritius, the historic significance of the independence ceremony is debunked by the preposterous twist of fictional fate which sees the container used as the podium on which the handover ceremony takes place. Hiding in the container, directly beneath the feet of the dignitaries, Laval and his friends believe that 'comme nous serions à la base du poteau, nous serions les premiers touchés et, forcément, tout changerait (since we would be at the base of the flagpole, we would be the first affected and so, inevitably, everything would change)' (125). In reality, however, as Laval comments :

Rien ne se passait en nous, nous ne sentions aucun pouvoir magique descendre le long du poteau et se glisser dans nos veines. Nous ne faisions que suer comme des ânes. C'était le jour de l'indépendance, et nous nous sentions comme des prisonniers dans une petite cellule étouffante. (Nothing happened inside us, we felt no magic power running down the flagpole and coursing through our veins. We were just sweating like pigs. It was Independence Day and we felt like prisoners in a stuffy little cell.) (125126)

Both Laval's expectations and the would-be pomp and ceremony of Mauritius's accession to independence are undermined by the bathos, banality and discomfort of the moment. As Laval iconoclastically concludes, 'l'Histoire était venue au Champ-de-Mars, s'y était posée un instant, puis s'était envolée vers d'autres pays, aux événements plus importants (History 
had come to the Champ-de-Mars, had paused there for a moment, and then had flown off to other countries, to more important events)' (127) - a sentiment which echoes Fitzgibbon's dismissive observation, in J'attendrai la fin du monde, that: 'vous n'êtes qu'un pays de plus à accéder à l'indépendance (you're just one more country to gain independence)' (131). Combined with both novels' focus on the inter-communal violence of the pre-independence period, Gordon-Gentil's and Sewtohul's deflating treatment of the independence ceremony highlights, in humorous fictional fashion, the contested and unstable foundations on which Mauritian independence was based.

In both J'attendrai la fin du monde and Made in Mauritius, the independence ceremony is recounted - and its historical importance undermined - by Mauritian characters whose official status, as colonial subjects or as citizens of the new nation, is directly and explicitly tied up with the handover of power. In Shenaz Patel's Le Silence des Chagos, however, the independence ceremony is depicted as experienced by outsiders: by Chagossian refugees for whom Mauritian independence holds very different connotations and consequences. Based on the real-life testimonies of Charlesia, Raymonde and Désiré, the interwoven 'histoires romancées (fictionalised stories/histories)' (Patel 2006) of Le Silence des Chagos recount the circumstances of the Chagossian people's expulsion from their homeland, the terrible hardships that they continue to suffer in their country of involuntary exile, and their vain yet abiding yearning to return home. ${ }^{18}$ As the novel gradually reveals, the forced displacement of the Chagossian islanders and the excision of their archipelago, were set as pre-conditions for Mauritian independence, in a highly secretive and illegal Cold War deal between Great Britain, the United States and Mauritius's Prime Minister, Sir Seewoosagur Ramgoolam. In Patel's novel, the independence ceremony is told as experienced, from the side-lines, by traumatised and marginalised newcomers, in a fragmented narrative which contrasts the loudly-celebrated proclamation of Mauritian 
independence, on the one hand, with the silenced and occluded deportation of the Chagossians, on the other. In so doing, Patel's novel chronicles the shameful circumstances that led to the involuntary and unwelcome addition of another, ethnic sub-group to the multicultural mix of the new 'rainbow nation' at its very inception - an ethnic group that continues to be doubly marginalised, as both black Creoles and as 'Ilois', in Mauritius's socio-ethnic hierarchy today. ${ }^{19}$

At two points in the novel, reflecting two different historical moments, Mauritian independence is viewed from the marginal perspective of Chagossian characters, in a way that casts an ironic, critical light on the triumphalist pomp and ceremony of official history. First, early in the novel, in a section set in Mauritius in 1968, the central character Charlesia overhears the sound of the independence canons, fired to mark the handover of power from the British to the new Mauritian government, from the squalor of her slum-dwelling on the geographic and social outskirts of Port Louis. As Charlesia then makes her way to the port for news of boats to or from her stolen homeland, the sounds of the 'historic' independence celebrations continue only fleetingly to intrude on her consciousness. Once at the portside, coverage of the celebrations is conveyed via the radio commentary to which the security guard Toni - himself only an oblique, auditory participant in events - is listening:

Historique, ce mot revenait sans cesse dans cette retransmission, il n'allait pas rater ça, pour une fois qu'il était dans l'Histoire, il voulait en savoir un maximum, pour en parler un jour à ses petits-enfants. Oui, j'étais là, enfin presque, je peux tout vous raconter. (Historic, that word kept coming up in the broadcast, he wasn't going to miss it, for once that he was part of History, he wanted to know as much as possible, to talk about it one day to his grandchildren. Yes, I was there, well almost, I can tell you everything.) (Patel 2005, 22)

Second, in the closing pages of the novel, set in Mauritius in the early 2000s, the full significance of the Chagossians' marginal but central experience of this defining moment in Mauritius's history is revealed to Désiré, a second-generation Chagossian, born during the 
sea crossing and whose own mother had since repressed all reference to his traumatic origins and to his people's silenced history. As Charlesia now recounts:

Ce n'est que longtemps après que nous avons appris le troc qui s'était effectué sur notre dos. Anglais et Américains avaient arrangé leur affaire. Et Maurice n'a rien fait pour nous défendre. Trop contente d'avoir son indépendance. (It wasn't until much later that we learnt of the exchange that we were unwittingly caught up in. English and Americans had done their deal. And Mauritius did nothing to defend us. Too pleased to have their independence.) (144) ${ }^{20}$

Charlesia's revelation in turn forces Désiré to reconsider the national and personal symbolism of the annual Independence Day celebrations, in which he had blithely participated as a schoolchild. He is forced to rethink his own position in relation to the (now absurd) nationalist rhetoric of the Mauritian anthem, proclaiming 'Gloire à toi Ile Mauriiiiiiiiice, ô ma mè-re patriiie (Glory to you, Mauritius Island, oh motherland)' (145). Whereas he had previously participated with childish ignorance in the celebrations, Désiré now retrospectively and self-assertively distinguishes between his own position and that of his 'fellow' Mauritians, and so between 'Son pays (his country)' and 'Leur indépendance (their independence)' (Patel 2005, 146).

The trauma, divisions, violence and secretive deals of the independence period have, until recently, been widely silenced and glossed over in efforts to paint a celebratory picture of the birth of the new Mauritian nation. After a rocky, unpromising start, Mauritius's subsequent economic, political and social successes have helped to perpetuate such positive, self-congratulatory discourse and to eclipse latent inequalities and tensions. In recent years, however - in the build-up to the fiftieth anniversary celebrations and in response to the Kaya riots - more critical literary voices have emerged, which have begun to probe the repressed aspects of the independence period and the new nation's birth. As we have seen, twenty-firstcentury novels, by Ananda Devi, Shenaz Patel, Amal Sewtohul and Alain Gordon-Gentil, 
have shed light on complex, internal, inter-ethnic tensions - between Hindus and Muslims; Hindus and Creoles; Creoles and Muslims - that marked the pre-independence period and threatened the nation's very transition to independence. Patel's novel, in particular, also helps to bring to public attention the shameful treatment of Chagos islanders, the longunacknowledged pawns in shady international deals over Mauritian independence and who continue to be victims of racism and social marginalisation today. Reflecting their common iconoclastic approach to official history, three of the four novels analysed depict the independence ceremony itself, in order to debunk the purported historical significance of the handover of power from the British to the new Mauritian government, and to reveal - in the case of Made in Mauritius, quite literally - the shaky foundations on which it was based.

So, what are we to make of these highly (self-)critical, iconoclastic representations of Mauritian independence and of the apparent precariousness of the post-colonial nation's multicultural harmony? Does the collective national portrait painted - of internal inter-ethnic unrest, marginalisation, competition and division - retrospectively confirm the dire predictions of Naipaul, Allen and others, and reveal, fifty years later, the fragility, complacency and delusion that underpin would-be grand narratives of Mauritian success? Or should such belated fictional focus on long-suppressed cracks, flaws and inequities be seen, rather, as a necessary stage in the construction of a more nuanced, balanced and genuinely inclusive vision of the post-colonial Mauritian nation? As Mauritian historians Vijayalakshmi Teelock and Ed Alpers warn, 'suppressing parts of our history only serves to delay further the process of reconciliation and increase the social fragmentation that is so apparent in Mauritius today' $(1999,9)$. Using Ricœur's theory of memory as an active exercise (see 2004), Srilata Ravi examines how literature 'as a form of cultural memory, remembers and/or forgets Mauritian histories [...] in ways that are different from other forms of public memorialisation' $(2014,156)$, particularly, in her own study, in relation to the ethnically- 
modularised commemoration of histories of slavery and indenture. Returning in fictional form to suppressed parts of Mauritius's more recent history in order to remember the turbulent circumstances of the nation's foundation, can be seen to contribute not just to a necessary process of reconciliation and social healing, but also to an ongoing process of inclusive nation-building that encompasses diverse experiences of, and relations to, the Mauritian nation.

Given the entirely non-indigenous, multi-ethnic composition of Mauritius's population, made up of descendants of immigrants from across the globe, a collective sense of Mauritian nationhood cannot be built on the traditional, imagined foundations of deep roots, ethnic or religious homogeneity, or a long-shared, common history (Anderson 1983). Rather, in returning fifty years later to the seemingly 'forgotten', but in fact shallowly suppressed, violence and internecine discord that marked the young nation's creation, the novels can be seen collectively to reflect Ernest Renan's famous postulation of the nation as 'un plébiscite de tous les jours (a daily plebiscite)' $(1882,27)$ unified not by ethnic homogeneity or ancestral ties but by 'une volonté commune dans le présent (a shared will in the present)' (26). Renan's famous lecture, 'Qu'est-ce qu'une nation?' (What is a nation?), is traditionally understood as a plea for forgetting such internecine conflict, in the interests of nation-building. Yet, paradoxically, by arguing that 'tout citoyen français doit avoir oublié la Saint-Barthélemy et les massacres du Midi au XIIIe siècle' (Renan, 9), as Anderson points out (200), 'Renan's readers were being told to “have already forgotten” what Renan's own words assumed that they naturally remembered!' Renan's plea, according to such an interpretation, is for selective memory, rather than for (impossible) forgetting of historic wrongs or for the active suppression of more recent, and hence more painful, memories. Referring directlyto France's seemingly 'forgotten' but in fact ever-present, history of internecine violence, massacre and revolutionary terror, Renan makes the more general 
assertion that 'l'unité se fait toujours brutalement (unity is always achieved brutally)' (8).

Applied to the different, multi-ethnic, multi-diasporic and much more recent historic context of Mauritius, where the two "crimes fondateurs (founding crimes) ${ }^{21}$ of slavery and indenture still structure collective memory and public commemoration, Renan's assertion invites more positive, inclusive interpretations of the inter-ethnic violence of the pre-independence period and of literary representations thereof. Recent literary representations of the traumas and divisions of Mauritian independence can thus be seen to embody what Ravi has called 'a new ethics of remembering' $(2013,64)$. Such an ethics of remembering, Ravi contends, 'does not imply the silencing of evil, but the task of speaking of evil in an appeased mode, without anger' (64). According to such a reading, acknowledgement of past, inter-ethnic unrest would constitute an essential part of, rather than a threat to, present and future processes of nationbuilding. Literary returns 'in an appeased mode' to the repressed episodes of Mauritius's foundation as an independent nation, fifty years on, can thus be seen to contribute - selfcritically, humorously, ironically, inclusively - to the ongoing project of national unity. The following sentiments, expressed by Renan in reply to his own question, 'Qu'est-ce qu'une nation? (What is a nation?)', have particular resonance for the ongoing process of Mauritian nation-building:

La nation [...] est l'aboutissant d'un long passé d'efforts, de sacrifices et de dévouements. [...] On aime en proportion des sacrifices qu'on a consentis, des maux qu'on a soufferts.

Dans le passé, un héritage de gloire et de regrets à partager, dans l'avenir un même programme à réaliser; avoir souffert, joui, espéré ensemble, $[. .$.$] voilà ce que$ l'on comprend malgré les diversités de race et de langue. [...L]a souffance en commun unit plus que la joie. En fait de souvenirs nationaux, les deuils valent mieux que les triomphes, car ils imposent des devoirs, ils commandent l'effort en commun. (The nation is the outcome of a long past of efforts, sacrifices and devotions. We love in proportion to the sacrifices we have made, to the wrongs we have suffered. / In the past, a legacy of glory and of regrets to share, in the future a common project to achieve: to have suffered, rejoiced, hoped together [...] that is what we understand despite differences of race and language. Shared suffering unites more than joy. As national memories, griefs are worth more than triumphs, since they enforce duties, they enjoin shared effort) (26-27). 
As twenty-first-century literary depictions of Mauritian independence suggest, it is only by recognising the sacrifices and suffering of different ethnic constituencies as shared 'souvenirs nationaux (national memories)', and by commemorating 'les deuils (the griefs)' along with 'les triomphes (the triumphs)' - even when, or particularly when, these 'deuils' were inflicted by fellow Mauritians from different ethnic groups - that national unity can begin to prevail over diversity and division. Debunking official grand narratives, the novels reveal cracks in the rainbow nation's celebratory façade of inter-ethnic harmony. In so doing, they create alternative, iconoclastic counter-narratives which integrate these now-acknowledged cracks and differences into the on-going work - or devoir - of shared Mauritian nationhood. The counter-discursive stories of the nation's foundation that these novels retrospectively tell thus represent an important, necessary part in a forward-looking, nation-building 'effort en commun (shared effort)' that may yet give imaginative, unifying meaning to the national slogan of 'unity in diversity'.

\section{References:}

Allen, Philip. 1966. 'Mauritius on the Eve'. Africa Report (11.5): 16-24

'An eye witness account of the 1968 riots', Mauritius Mag (6 October 2011), www.mauritiusmag.com/?p=598

Anderson, Benedict. 2006 [1983]. Imagined Communities: Reflections on the Origin and Spread of Nationalism. London and New York: Verso.

Boswell, Rosabelle. 2006. Le Malaise Créole: Ethnic Identity in Mauritius (Oxford: Berghahn.

Bowman, Larry W. 1991. Mauritius: Democracy and Development in the Indian Ocean. Boulder: Westview Press.

Collen, Lindsey. 2009. 'Another side of paradise'. New Internationalist (2 May). Accessed at: https://newint.org/features/2009/05/01/mauritius-class/

Devi, Ananda. 2009. Le Sari vert. Paris: Gallimard.

Dinan, Monique, Vidula Nababsing and Hansraj Mathur. 1999. 'Mauritius: Cultural Accommodation in a Diverse Island Polity'. In The Accommodation of Cultural Diversity: Case Studies, edited by Crawford Young. Basingstoke: Macmillan, 72-102 Eriksen, Thomas Hylland. 1998. Common Denominators: Ethnicity, Nation-Building and Compromise in Mauritius. Oxford: Berg. 
Eriksen, Thomas Hylland. 1999. 'Tu dimunn pu vini kreol: The Mauritian creole and the concept of creolization'. Accessed at http://folk.uio.no/geirthe/Creoles.html

Frankel, Jeffrey. 2010. Mauritius: African Success Story, HKS Faculty Research Working Paper Series. Accessed at http://nrs.harvard.edu/urn-3:HUL.InstRepos:4450110

Gordon-Gentil, Alain, J'attendrai la fin du monde (Paris: Julliard, 2016)

Jeffery, Laura. 2011. Chagos Islanders in Mauritius and the UK. Manchester: Manchester University Press.

Houbert, Jean. 1981. 'Mauritius: Independence and Dependence'. The Journal of Modern African Studies (19.1): 75-105.

Lionnet, Françoise. 1993. 'Créolité in the Indian Ocean: Two Models of Cultural Diversity'. Yale French Studies (82): 101-112

Minogue, Martin, 1992. 'Mauritius: Economic Miracle or Developmental Illusion?', Journal of International Development (4.6): 643-47

Naipaul, V.S. 1972. 'The Overcrowded Baracoon,' Sunday Times Magazine (16 July).

Reproduced in The Overcrowded Baracoon. 1984. New York: Vintage Books, 255-86.

Patel, Shenaz, 2005. Le Silence des Chagos. Paris: Editions de l'Olivier.

Patel, Shenaz. 2006. 'Pourquoi ce livre', accessed at

http://kiltir.com/francais/b0033/silence_chagos_pourquoi.shtml.

Ravi, Srilata. 2010. 'Indo-Mauritians: National and Postnational Identities', L'Esprit créateur (50.2): 29-45

Ravi, Srilata. 2013. Rethinking Global Mauritius: Critical Essays on Mauritian Literatures and Cultures. Trou d'Eau Douce: L'Atelier d'écriture.

Ravi, Srilata, 2014. 'Multiple Memories: Slavery and Indenture in Mauritian Literature in French'. In At the Limits of Memory: Legacies of Slavery in the Francophone World, edited by Nicholas Frith and Kate Hodgson. Liverpool: Liverpool University Press, 154-72.

Ricœur, Paul. 2000. La Mémoire, l'histoire, l'oubli. Paris: Seuil.

Renan, Ernest, 1882. 'Qu'est-ce qu'une nation?'. Paris: Calmann Lévy.

Sewtohul, Amal. 2012. Made in Mauritius. Paris: Gallimard.

Subramanian, Arvind and Devesh Roy. 2003. 'Who Can Explain the Mauritian Miracle?'. In: In Search of Prosperity, edited by Dani Rodrik. Princeton: Princeton University Press, 20543

Sultan, Patrick. 2001. 'Rupture et héritages: Entretien avec Ananda Devi'. Accessed at http://orees.concordia.ca/numero2/essai/Entretien7decembre.html

Teelock, Vijayalakshmi and Ed Alpers, eds. 1999. History, Memory and Identity. Port Louis: University of Mauritius Press.

Vine, David. 2009. Island of Shame: The Secret History of the U.S. Military Base on Diego Garcia. Princeton: Princeton University Press.

Waters, Julia. 2018. The Francophone Mauritian Novel: Fictions of Belonging. Liverpool: Liverpool University Press.

\footnotetext{
${ }^{1}$ This phrase, roughly translated as 'the smouldering years' is from Sewtohul's novel, Made in Mauritius (2012, 197), and is frequently used to describe the tense, highly-charged atmosphere of the independence period, when a resurgence of inter-ethnic violence was a constant threat. The idiomatic phrase encompasses connotations of latent heat (braise, embers) and of tension (on tenterhooks, walking on eggshells). All translations in this article are my own.

${ }^{2}$ Most famously, V.S. Naipaul (1984 [1972], 257 and 270) described Mauritius soon after independence as an 'island of disaster' whose 'problems defy solution.'
} 


\section{${ }^{3}$ With no original, in-dwelling inhabitants, Mauritian society is made up entirely of the descendants of}

immigrants - mainly from France, Africa, Madagascar, different parts of India, and China - who were brought to the island, over the past three centuries, by the brutal transnational flows of slavery, indenture, imperialism, global capitalism and economic migration. The Mauritian constitution recognises four ethnic or religious 'communities': Hindus (48\%), Muslims (17\%), Sino-Mauritians (2\%) and the 'General Population'. The last category includes 'every person who does not appear, from his way of life, to belong to one or other of those three categories' and hence includes both Franco-Mauritians (2\%) and Creoles (27\%). There is great diversity within these classifications. The proportions are based on dated census data and hence likely to be inaccurate. ${ }^{4}$ As Thomas Eriksen (1999) observes, the term 'Creole' is generally used in Mauritius to refer 'not only to slave ancestry and cultural impurity, but to low class'. Consequently, when a Creole moves upwards, he or she has traditionally been re-defined as a 'coloured' (gens de couleur), in other words as someone aspiring to European or Franco-Mauritian values'. No page numbers in original.

${ }^{5}$ As Allen's terminology here reflects, in the Mauritian context, the largely discredited term 'race'is widely used interchangeably with those of religion, ethnicity or even class, to distinguish different 'communities' from each other. 'Hindu' thus connotes 'Indo-Mauritian'; 'Catholic' connotes 'Creole' or, less often, 'Afro-Mauritian', and so forth. Throughout this article, I maintain the terminology used in the original texts, despite the problematic inconsistencies that sometimes arise.

${ }^{6}$ Collen, Lindsey, 'Another side of paradise', New Internationalist (2 May 2009). Accessed at: https://newint.org/features/2009/05/01/mauritius-class/. No page numbers in original.

${ }^{7}$ As Eriksen $(1998,145)$ notes, "the concept "unity in diversity" represents a contradiction in terms for many Mauritians.'

${ }^{8}$ As a direct response to inter-ethnic unrest, mechanisms to defend minority interests, including communal parliamentary representation (by means, for instance, of the much-debated 'best loser' system) and a civil rights ombudsman, were written into the independence constitution.

${ }^{9}$ For instance, Françoise Lionnet $(1993,106)$ lauds Mauritius as 'a superb example of successful mediations of the uncertain relationship between nationhood and ethnic or cultural identity', contrasting its harmonious, postcolonial, multicultural stability with the turbulent inter-ethnic rioting that had recently racked nearby Île de la Réunion. Thomas Eriksen (1998, 10 and 169) stresses that 'there has been no public, violent ethnic unrest since 1969 ', an absence of violence which he interprets as a positive indication that 'Mauritians can be a people tomorrow if they decide to'. Dinan et al. $(1999,101)$ praise the Mauritian government for its successful accommodation of cultural diversity, dismissing various 'minor incidents' of religious and communal fundamentalism on the grounds that they 'could in no way be compared to the more serious outbreaks of racial violence which occurred in the few years preceding independence'.

${ }^{10}$ For a study of contemporary Mauritian fiction's response to the Kaya unrest and the alternative, non-ethnic forms of belonging that it imagines, see: Julia Waters, The Francophone Mauritian Novel: Fictions of Belonging (Liverpool: Liverpool University Press, 2018).

${ }^{11}$ Horace is the fictional illegitimate offspring of the famous French poet Charles Baudelaire's brief romance with a 'dame Créole' during his visit to Île de France.

${ }^{12}$ In reality, the last British governor of Mauritius, 1962-1968, was John Shaw Rennie.

${ }^{13}$ Gordon-Gentil's novel explicitly underlines the racism that motivated the anti-independence sentiments of those who preferred to emigrate than live in 'Little India', by stressing the symbolism of their preferred countries of destination, South Africa and Australia, both known for their state-sanctioned oppression of the indigenous, black populations. A similar point is implicitly made, in Made in Mauritius, when Laval is reunited with Faisal, a Mauritian Muslim, in the Australian outback where he lives amongst impoverished Aborigines and other non-white social outcasts.

${ }^{14}$ In this regard, Devi's novel reflects Philip Allen's observation of the 'frequent phenomenon' whereby local 'purely Mauritian communal fever' $(1966,20)$ tended to echo and replicate broader international political disputes, notably between India and Pakistan.

${ }^{15}$ This threat is highlighted in Devi's Le Sari vert, when the narrator comments that, 'La guerre civile semblait imminente. (Civil war seemed imminent.)' (128)

${ }^{16}$ Saint François, like the larger quartiers of Roche Bois and Plaine Verte, was previously an ethnically mixed area that became suddenly and enduringly segregated as a result of Muslim-Creole violence. For recent eyewitness testimony of the real-life unrest in these districts, see 'An eye witness account of the 1968 riots', Mauritius Mag (6 October 2011), www.mauritiusmag.com/?p=598. Accessed 20 July 2017.

${ }^{17}$ Collen, Lindsey, 'Another side of paradise', New Internationalist (2 May 2009). Accessed at: https://newint.org/features/2009/05/01/mauritius-class/. No page numbers in original.

${ }^{18}$ For a powerful account of this particularly shameful episode of Cold War politics, see David Vine, 2009.

${ }^{19}$ For studies of racist attitudes towards Chagossians in Mauritius, see: Boswell (2006) and Jeffery (2011).

${ }^{20}$ Charlesia's words here echo Vine's assertion that the 'Chagossians $[\ldots]$ gave up their homeland so the rest of Mauritius could have its independence' $(2009,143)$. 
${ }^{21}$ In interview (Sultan, 2001), Devi describes slavery and indenture in these terms. No page numbers in original. 